\title{
The goat mammary gland as a model infection site for Neisseria gonorrhoeae
}

\author{
A. E. PASIEKA, F. OTA*, A. RYAN, F. E. ASHTON, R. WALlACE, C. PERUSSE, \\ AND B. B. DIENA \\ Bacterial Immunology Division, Laboratory Centre for Disease Control, Health Protection Branch, Health \\ and Welfare, Ottawa, Ontario, K1A 0L2, Canada
}

\begin{abstract}
Summary
Live and formalin-killed gonococci were instilled into the mammary glands of lactating and nonlactating goats. In lactating goats viable gonococci elicited a limited inflammatory process whereas in non-lactating goats, severe inflammation and swelling appeared and peaked on the 3rd day after instillation and persisted for about 10 days. No viable gonococci were recovered after the first day, but fluorescent antibody staining showed gonococci in the exudate from non-lactating goats up to 7 days after instillation.
\end{abstract}

\section{Introduction}

Research in gonorrhoea has been handicapped by the lack of an experimental animal infection model for Neisseria gonorrhoeae. Brown, Lucas, and Kuhn (1972) reported infection of the urogenital tract of the chimpanzee with gonococci, but the need remains for a less expensive animal that is easier to handle. Arko (1972) and Flynn and Waitkins (1973) reported that growth of $N$. gonorrhoeae took place in semipermeable chambers implanted in the lumbar region of rabbits and other animals. Buchanan and Gotschlich (1973) and Baumgarner and Finkelstein (1973) developed a model infection of the chick embryo with $N$. gonorrhoeae and Diena, Ryan, Ashton, Wallace, Perry, and Daoust (1975) reported intracerebral infection of HPB black mice with gonococci. However, the value of all of these techniques for immunological studies remains to be determined.

The purpose of this work was to establish gonogoccal infection in animals which would mimic human infection. We therefore investigated the goat mammary gland as a possible infection site for $N$. gonorrhoeae because of a number of similarities to the lower genitourinary tract of man:

Received for publication June 10, 1975

^Present Address: Department of Bacteriology, Tokushima University School of Medicine, Kuramoto-Cho, Tokushima, Japan (a) The internal mucosa is easily accessible;

(b) Inoculated bacteria may be flushed away by milk, analogous to urine in the genitourinary tract;

(c) Secretory globulins are considered an important defence mechanism in both the mammary gland and the genitourinary tract.

In addition, goats are easy to handle and large samples of milk and blood can be obtained.

\section{Material and methods}

\section{(a) Instillation}

Lactating and non-lactating goats were obtained from a local breeder; complete details of this technique have been previously described (Pasieka, Guerin, and Mitchell, 1970, 1975; Pasieka, Calver, Kenny, Perusse, Guerin, and Mitchell, 1975).

\section{(b) Strains}

N. gonorrhoeae 188 and G9 (Perry, Daoust, Diena, Ashton, and Wallace, 1974) and strain MEL-gp10V (Arko, 1972) were used. All strains were colony type 1 (Kellogg, Peacock, Deacon, Brown, and Pirkle, 1963).

\section{(c) Bacterial challenge}

Cultures of $N$. gonorrhoeae, grown for $16 \mathrm{hrs}$ on Gc agar plus defined supplement (GcDS) (Diena and others, 1975) were suspended in Dulbecco's phosphate buffered saline $\mathrm{pH} 7 \cdot 2$, containing $0 \cdot 1$ per cent. gelatin (DPBG). The suspensions were prepared to give, when diluted $1: 50$, an optical density of 0.5, using a Bausch and Lomb Spectronic 20 at $540 \mathrm{~nm}$ (equivalent to $10^{9}$ colony forming units $/ \mathrm{ml}$.).

(d) Recovery of N. gonorrhoeae

Tests for the presence of gonococci in infected mammary glands, consisted of inserting a sterile platinum loop into the teat canal and streaking on to Thayer-Martin selective medium (Thayer and Martin, 1966), GcDS, and Robert's $L$ form medium (Roberts, 1966).

(e) Serum and whey samples

Goats were bled and milked before instillation and then weekly for 2 months. Milk and blood serum were prepared as previously described (Pasieka, Calver, and others, 1975). 


\section{Results and discussion}

Lactating goats were instilled with suspensions of $N$. gonorrhoeae standardized to contain known amounts of micro-organisms. After preliminary tests, it became apparent that a dose of 2.5 to $5 \times 10^{10}$ gonococci was required to produce a limited inflammatory response in the mammary glands of these goats. Minor swelling occurred in the gland after 48 to $72 \mathrm{hrs}$ and pus accumulated in the teat. Viable gonococci were recovered from injected glands only up to $18 \mathrm{hrs}$ after instillation (Figure): L colonies were not recovered on either GcDS or Robert's medium. Generally, as a result of the infection, lactation was inhibited, but only for a few days. Instillation of formalin-killed $N$. gonorrhoeae in control goats evoked neither inflammation nor swelling.

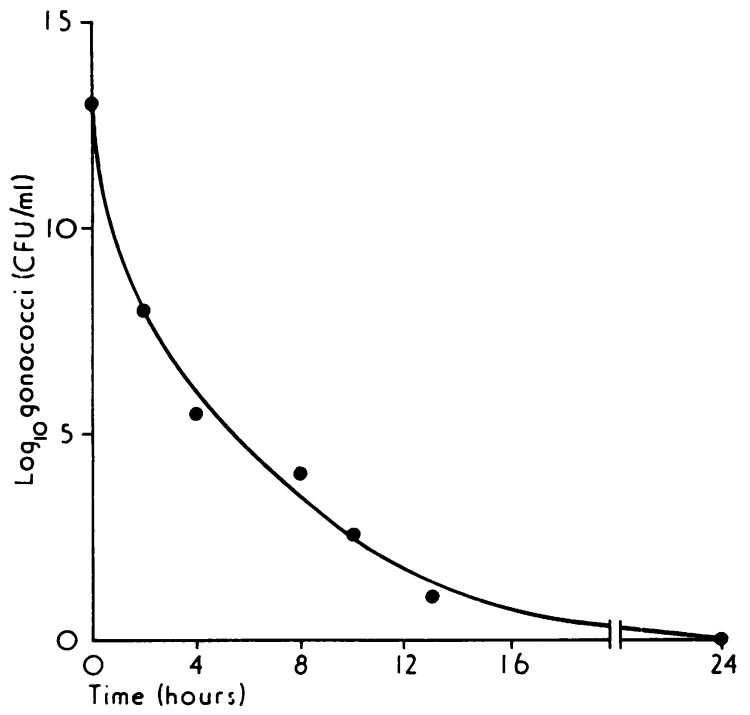

FIGURE Recovery of N. gonorrhoeae from mammary gland of lactating goats

In a second series of experiments, ten non-lactating goats were challenged with live strains of $N$. gonorrhoeae: 188, G9, and MEL-gp10V. In these goats, the right side of the gland was instilled with various doses of viable organisms, and the left side, as the control, was instilled with formalin-killed gonococci. In all cases, severe inflammation and swelling appeared only on the right side which had been instilled with doses of 1 to $2 \times 10^{10}$ viable gonococci. Inflammation appeared to peak on the third day after instillation and persisted for about 10 days. Viable $N$. gonorrhoeae were recovered from the infected glands for up to $18 \mathrm{hrs}$ after instillation. Thereafter, cultures from the exudate were invariably negative. Fluorescent antibody staining (Peacock, 1970), how- ever, showed organisms in the exudate up to 7 days after instillation. The apparent inability of the gonococci to survive in the pus of the teat canal of the infected mammary gland for an extended period of time is not too surprising, as Ward, Glynn, and Watt (1972) showed that gonococci degenerated in 30 to $60 \mathrm{~min}$. after phagocytosis by polymorphonuclear leucocytes. It is interesting to note that of all microorganisms previously instilled into the goat mammary gland (Pasieka and others, 1970, 1975), only live gonococcal cells have evoked swelling and inflammation.

Bentonite flocculating antigonococcal antibodies were first detected in serum of lactating and nonlactating goats 1 week after instillation of $N$. gonorrhoeae and in whey of lactating goats at the same time. Details of the immunological response of the goats to instillation with live and formalin-killed gonococci will be reported elsewhere.

Experiments are presently being undertaken to determine the efficacy of experimental vaccines to protect the goat against this model infection.

The technical assistance of Mrs. M. E. Thomas is gratefully acknowledged. Special thanks are due for excellent animal husbandry and care, to Mr. J. Simmons and L. Irwin, Animal Resources Division, Health Protection Branch, Health and Welfare, Canada.

\section{References}

ARko, R. J. (1972) Science, 177, 1200

BAUMGARNER, L. R., and FINKELSTEIN, R. A. (1973) Infect. and Immun., 8, 919

Brown, W. J., LuCAS, C. T., and KuHN, U. S. G. (1972) Brit. F. vener. Dis., 48, 177

BuCHANAN, T. M., and GotsChLICH, E. C. (1973) F. exp. Med., 137, 196

Diena, B. B., Ryan, A., Ashton, F. E., Wallace, R., PERRY, M. B., and DaOust, V. (1975) Brit. F. vener. Dis., 51, 22

FlynN, J., and Waitkins, S. A. (1973) Ibid., 49, 432

KellogG, D. S., Jr., Peacock, W. L., Deacon, W. E., Brown, L., and PIRKLe, C. I. (1963) f. Bact., 85, 1274

Pasieka, A. E., Calver, G., Kenny, C. P., Perusse, C., GUERIN, L. F., and Mitchell, C. A. (1975) Canad. f. Microbiol., 21, 662

- GuERIN, L. F., and Mitchell, C. A. (1970) Ibid., 16, 1153

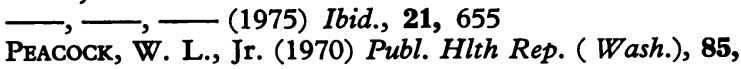
733

Perry, M. B., Daoust, V., Diena, B. B., Ashton, F. E., and WALLACE, R. (1974) WHO/VDT/RES/GON/74.87

ROBERTS, R. B. (1966) F. Bact., 92, 1609

ThaYER, J. D., and MarTin, J. E., Jr. (1966) Publ. Hlth Rep. (Wash.), 81, 559

WARD, M. E., GLYNN, A. A., and WatT, P. J. (1972) Brit. F. exp. Path., 53, 289 